\title{
KORELASI ANTARA PENGUASAAN KOSAKATA BAHASA JERMAN DENGAN KETERAMPILAN MENULIS KALIMAT SEDERHANA SISWA KELAS X SMA NEGERI 1 ALLA KABUPATEN ENREKANG
}

\author{
Ririn Ismiyanti ${ }^{1}$ dan Muddin ${ }^{2}$ \\ Bahasa dan Sastra, Universitas Negeri Makassar \\ E-mail1': ririn_ismiyanti@yahoo.co.id
}

\begin{abstract}
ABSTRAK
Penelitian ini bertujuan untuk mengetahui korelasi antara penguasaan kosakata bahasa Jerman dengan keterampilan menulis kalimat sederhana siswa kelas X SMA Negeri 1 Alla Kabupaten Enrekang. Pengumpulan data pada penelitian ini dilakukan dengan tes tertulis dan dianalisis melalui korelasi Product Moment. Populasi penelitian ini adalah siswa kelas X IPA yang berjumlah 224 orang. Sampel penelitian ini adalah 31 siswa kelas X IPA 1 yang dipilih melalui teknik Total Sampling. Hasil analisis data menjelaskan bahwa $r_{\text {hiung }}=0,783>r_{\text {tabel }}=0,355$. Hasil penelitian menunjukkan bahwa ada korelasi yang signifikan antara penguasaan kosakata bahasa Jerman dengan keterampilan menulis kalimat sederhana siswa kelas X SMA Negeri 1 Alla Kabupaten Enrekang.
\end{abstract}

Kata Kunci: Pendekatan Korelasi, Penguasaan Kosakata, Keterampilan Menulis

\begin{abstract}
This study aimed to determine the correlation between vocabulary mastery of the German language with the skill of simple sentence writing class X SMA Negeri 1 Alla Enrekang. Data was collected by using written test and data analysis done by using product moment correlation. The study population was the class X IPA which amounted 224 students. The sample was 31 students of class X IPA 1 selected through the total sampling technique. The result of data analysis explained that $r$ value $=0.783>r$ table $=0.355$. It showed that there was a significant correlation between vocabulary mastery of the German language with the skill of simple sentence writing class X SMA Negeri 1 Alla Enrekang.
\end{abstract}

Keywords: Correlation Approach, Vocabulary Mastery, Writing Skill

\section{PENDAHULUAN}

Bahasa adalah sesuatu yang tidak dapat dipisahkan dari kehidupan manusia. Bahasa merupakan alat untuk berkomunikasi atau alat interaksi sesama manusia. Bahasa dapat menyampaikan suatu pikiran satu sama lain dalam kehidupan manusia. Melalui bahasa terungkap sesuatu yang ingin disampaikan pembicara kepada pendengar, penulis kepada pembaca, dan penyapa kepada pesapa. Sebagai makhluk sosial, manusia membutuhkan bahasa sebagai modal dasar dalam berkomunikasi. Tanpa komunikasi, seseorang tidak dapat berinteraksi dengan orang lain. Dari bahasa semua orang dapat mengetahui informasi dari segala penjuru dunia, tidak hanya dari 
dalam negeri tapi bahkan luar negeri, sehingga bahasa asing mengambil peran penting.

Bahasa Jerman juga dimasukkan dalam Kurikulum Nasional yang telah diajarkan di bangku pendidikan jenjang Sekolah Menengah Atas (SMA), Sekolah Menengah Kejuruan (SMK) dan Madrasah Aliyah (MA). Siswa diarahkan untuk terampil menggunakan bahasa tersebut dalam berinteraksi baik secara langsung maupun tidak langsung dengan orang di sekelilingnya. Melalui pengajaran bahasa Jerman siswa dapat terampil dalam berbahasa.

Salah satu kompetensi berbahasa yang penting untuk dikembangkan dalam pembelajaran bahasa Jerman adalah keterampilan menulis, karena dengan menulis siswa dapat menuangkan ide dan pikirannya dalam bentuk tulisan. Keterampilan menulis merupakan salah satu kompetensi yang penting dalam proses belajar mengajar, karena pada dasarnya keterampilan menulis sering digunakan dalam mengerjakan tugas di antaranya membuat kalimat, menulis karangan, menulis surat dan sebagainya.

Dalam pembelajaran menulis bahasa Jerman, siswa dilatih untuk membuat kalimat bahasa Jerman dengan baik dan benar. Namun siswa memiliki kendala dalam pembelajaran menulis. Hal ini disebabkan minimmya penguasaan kosakata siswa yang membuat mereka sulit dalam membuat kalimat. Penguasaan kosakata siswa sangat membantu dalam membuat suatu kalimat, karena dapat menunjang kualitas keterampilan menulis siswa.

Kajian dalam penelitian ini difokuskan pada keterampilan menulis kalimat sederhana bahasa Jerman. Dalam menulis kalimat sederhana bahasa Jerman perlu penguasaan kosakata yang memadai. Penguasaan kosakata dalam menulis kalimat sederhana bahasa Jerman memberikan konstribusi yang sangat besar. Dengan kata lain siswa yang tidak memiliki penguasaan kosakata yang baik akan mengalami kesulitan dalam membuat kalimat khususnya kalimat sederhana dalam bahasa Jerman. Semakin banyak kosakata yang dimiliki siswa, semakin baik pula keterampilan menulis siswa, dalam hal ini adalah keterampilan menulis kalimat sederhana bahasa Jerman. Sebagaimana pendapat yang dikemukakan oleh Tarigan (2011:2) bahwa kualitas keterampilan berbahasa seseorang sangat dipengaruhi pada kualitas dan kuantitas kosakata yang dimilikinya. Semakin kaya kosakata yang dimiliki, semakin terampil pula dalam berbahasa.

Berdasarkan pengalaman dan pengamatan lapangan yang dilakukan saat Praktek Pengalaman Lapangan (PPL) di SMA Negeri 11 Makassar pada bulan September sampai Desember 2015, diketahui bahwa siswa masih mengalami kesulitan dalam menulis kalimat bahasa Jerman terkhusus pada penulisan kalimat sederhana. Dari pengamatan di dalam kelas yang dilakukan oleh 
penulis, dikemukakan beberapa faktor yang melatarbelakangi kesulitan siswa dalam menulis kalimat bahasa Jerman. Salah satu di antaranya adalah minimnya kosakata yang dimiliki para peserta didik yang sangat berpengaruh terhadap keterampilan menulis mereka khususnya keterampilan menulis kalimat sederhana bahasa Jerman, kurangnya motivasi siswa dalam belajar bahasa Jerman, karena mereka menyepelekan pelajaran bahasa Jerman. Selain itu, dari dokumen hasil belajar siswa yang diperoleh dari Guru khususnya keterampilan menulis kalimat sederhana bahasa Jerman pada bagian penugasan menunjukkan persentase yang rendah. Hal ini disebabkan karena rendahnya penguasaan kosakata yang mereka miliki. Penguasaan kosakata yang rendah membuat mereka kesulitan dalam membuat kalimat sederhana bahasa Jerman.

Hal di atas didukung oleh hasil penelitian sebelumnya oleh Pua (2013: 62) disimpulkan bahwa keterampilan menulis siswa memperoleh nilai rata-rata 4,27 dengan angka persentase $61 \%$ yang berada dalam kategori cukup. Penelitian lain yang dilakukan oleh Saadiah (2013: 46) disimpulkan bahwa penguasaan kosakata siswa termasuk dalam kategori cukup dengan nilai rata-rata 65,28 . Sedang dalam penelitian Irhana (2015: 48) dinyatakan bahwa hubungan antara penguasaan kosakata dengan keterampilan menulis surat pribadi bahasa Jerman termasuk dalam kategori sangat kuat dengan koefisien korelasi sebesar 0,877 . Hal inilah yang mendorong peneliti untuk melihat apakah ada korelasi antara penguasaan kosakata bahasa Jerman dengan keterampilan menulis kalimat sederhana.

Berdasarkan uraian di atas, maka perlu dilakukan penelitian dengan judul "Korelasi antara Penguasaan Kosakata Bahasa Jeman dengan Keterampilan Menulis Kalimat Sederhana siswa kelas $\mathrm{X}$ SMA Negeri 1 Alla Kabupaten Enrekang".

\section{PENGUASAAN KOSA KATA}

Ulrich (2007: 3) menyatakan bahwa "Wörter sind unser Tür zur Welt, Wörter sind unser Weg zu den Menschen: Sie ermöglichen uns das Denken, sie sind die Grundlage unserer Verständigung miteinander". Dijelaskan, bahwa kata merupakan gerbang dunia, kata adalah sarana untuk menjalin komunikasi sesama manusia: kata-kata memungkinkan kita untuk berpikir, kata-kata merupakan dasar untuk saling berkomunikasi dengan orang lain. Soedjito (1992: 21) menambahkan kosakata atau perbendaharaan kata adalah: (1) semua kata yang terdapat dalam suatu bahasa, (2) kekayaan kata yang dimiliki oleh seorang pembicara atau penulis, (3) kata yang dipakai dalam suatu bidang ilmu pengetahuan.

Rivers (dalam Nunan, 1991: 117) berpendapat bahwa penggunaan suatu kosakata yang cukup itu penting 
untuk berhasilnya penggunaan bahasa kedua karena tanpa jumlah kosakata yang banyak, kita tidak akan dapat menggunakan struktur dan fungsi yang telah kita pelajari untuk komunikasi yang komprehensif. Oleh karena itu, dibutuhkan penguasaan kosakata yang banyak agar terjadi komunikasi yang baik terutama komunikasi dengan menggunakan bahasa asing.

Nurgiyantoro (2010: 338) menyatakan bahwa penguasaan kosakata dapat dibedakan kedalam penguasaan yang bersifat reseptif dan produktif, kemampuan untuk memahami dan mempergunakan kosakata. Kemampuan memahami kosakata terlihat dalam kegiatan membaca dan menyimak, sedangkan kemampuan mempergunakan kosakata nampak dalam kegiatan menulis dan berbicara.

$$
\text { Djiwandono (2011: }
$$

menyatakan bahwa penguasaan kosakata yang merupakan bagian dari penguasaan bahasa dibedakan dalam penguasaan aktif-produktif dan pasifreseptif. Pengertian penguasaan kosakata aktif-produktif yaitu kosakata yang telah dikuasai dan dipahami dapat digunakan oleh siswa bahasa secara wajar tanpa adanya kesulitan dalam berkomunikasi atau berbahasa. Penguasaan pasif-reseptif merupakan kosakata yang dikuasai hanya dapat dipakai oleh pembelajar bahasa dari ungkapan bahasa orang lain, tetapi ia tidak mampu menggunakan kosakata secara wajar dalam berkomunikasi atau berbahasa.

\section{KETERAMPILAN MENULIS KALIMAT SEDERHANA}

$$
\text { Haryati (2006: }
$$

membedakan keterampilan menjadi dua macam, yaitu keterampilan psikomotorik dan keterampilan yang berhubungan dengan kegiatan fisik yang berupa kebiasaan bekerja dengan menggunakan alat, sedangkan keterampilan intelektual merupakan keterampilan yang berhubungan dengan mental yaitu kegiatan berupa kegiatan berpikir kritis seperti memecahkan masalah.

\section{Zainurrahman}

(2011:

menyatakan bahwa keterampilan bahasa dibagi menjadi dua jenis, yaitu keterampilan yang biasa diperoleh secara alami dan keterampilan yang hanya diperoleh melalui latihanlatihan dan penguasaan konsep tertentu. Sedangkan Junus dan Junus (2011:10) berpendapat bahwa keterampilan ialah kemampuan yang disertai dengan kemahiran melakukan sesuatu. Untuk memilikinya diperlukan latihan yang teratur bahkan remedial.

Kegiatan menulis pada pembelajaran bahasa asing dianggaptugas yang paling susah. Dalam penelitian Faistauer, menunjukkan bahwa pembelajar bahasa Jerman dapat menyelesaikan tugas menulisnya lebih baik jika mereka menulis dalam kelompok.

$$
\text { Djiwandono (2011: }
$$

menjelaskan bahwa kegiatan menulis merupakan suatu usaha untuk mengungkapkan pikiran dan perasaan yang ada pada diri seorang pemakai bahasa melalui tulisan. Ba'dulu 
(2005: 50) juga menyatakan bahwa kalimat sederhana adalah kalimat yang terdiri dari klausa sederhana. Chaer (2006: 329) menyatakan bahwa kalimat sederhana dibentuk dari sebuah klausa yang unsur- unsurnya berupa kata atau frasa sederhana. Sedangkan Putrayasa (2012: 41) berpendapat bahwa kalimat sederhana yaitu kalimat yang hanya terdiri atas dua unsur inti dan boleh diperluas dengan satu atau lebih unsur-unsur tambahan, asal unsur-unsur tambahan tersebut tidak boleh membentuk pola yang baru.

\section{METODE PENELITIAN}

Dalam penelitian ini, digunakan dua variabel yaitu penguasaan kosakata bahasa Jerman siswa sebagai variabel bebas (X) dan keterampilan menulis kalimat sederhana bahasa Jerman sebagai variabel terikat $(\mathrm{Y})$.

Penelitian ini merupakan penelitian deskriptif korelasi yang bertujuan untuk mengetahui hubungan antara penguasaan kosakata bahasa Jerman dengan keterampilan menulis kalimat sederhana siswa kelas $\mathrm{X}$ bahasa SMA Negeri 1 Alla Kabupaten Enrekang.

Penguasaan kosakata yang dimaksud dalam penelitian ini adalah suatu aktifitas dalam menguasai dan menggunakan kata-kata yang terdapat dalam suatu bahasa, baik lisan maupun tulisan. Apabila penguasaan kosakata belum baik, maka siswa tidak dapat menulis dengan baik pula. Kosakata yang harus siswa kuasai meliputi: 1) Kata benda (Nomen), 2) Kata kerja (Verb), 3) Kata sifat (Adjektiv) dan 4) Kata penghubung (Konjunktion). 5) Kata bilangan (Zahlwörter).

Keterampilan menulis yang dimaksud adalah suatu usaha untuk mengungkapkan pikiran, ide dan perasaan ke dalam bentuk tulisan, serta menggambarkan apa yang mereka pahami dalam bentuk kalimat sederhana. Kalimat sederhana yang dimaksud adalah kalimat yang terdiri dari subjek, predikat, objek, dan keterangan tempat maupun keterangan waktu. Penelitian ini memfokuskan pada menulis kalimat sederhana bahasa Jerman sesuai dengan tema kelas $\mathrm{X}$ yaitu Die Schule.

Populasi dalam penelitian ini adalah seluruh siswa kelas X IPA SMA Negeri 1 Alla Kabupaten Enrekang yang terdiri dari tujuh kelas dengan jumlah siswa 224 orang. Mengingat banyaknya jumlah populasi dalam penelitian ini, maka ditetapkan seluruh siswa kelas X IPA 1 SMA Negeri 1 Alla Kabupaten Enrekang dengan jumlah siswa sebanyak 31 orang sebagai sampel dengan menggunakan teknik random sampling (sampel acak).

Untuk memeroleh data dalam penelitian ini digunakan 2 macam tes, yaitu tes kosakata dan tes menulis kalimat sederhana bahasa Jerman. Analisis data dalam penelitian ini akan menggunakan analisis statistik parametric. Sebelum menguji hipotesis, terlebih dahulu menghitung uji normalitas, uji 
homogenitas dan uji Linieritasnya, kemudian menguji hipotesis dengan menggunakan analisis korelasi Product Moment, uji signifikansi, uji persamaan regresi sederhana dan uji koefisien determinasi.

\section{PEMBAHASAN}

\section{Hasil Analisis Data Tes Penguasaan Kosakata}

Data yang diperoleh dari penelitian untuk variabel penguasaan kosakata, skor terendah yang dicapai siswa adalah 23 dan skor tertinggi yang dicapai siswa adalah 44 . Berdasarkan data yang telah diolah dari kelima macam tes kosakata yang telah diberikan, maka skor rata-rata yang diperoleh siswa pada tes menentukan kata benda adalah 7 , kemudian skor rata-rata pada tes menentukan kata sifat adalah 8,61 selanjutnya pada tes menentukan kata kerja adalah 6,64 dan tes menentukan kata penghubung adalah 7,09 serta skor rata-rata yang diperoleh pada tes menentukan kata bilangan adalah 6,54 .

\section{Hasil Analisis Tes Keterampilan Menulis Kalimat Sederhana}

Data yang diperoleh dari penelitian untuk variabel keterampilan menulis kalimat sederhana, skor terendah yang dicapai siswa adalah 3 dan skor tertinggi yang dicapai siswa adalah 8 ..

\section{Hasil Analisis Uji Prasyarat}

\section{a. Hasil Analisis Uji Normalitas}

Uji normalitas merupakan uji yang dilakukan untuk mengetahui apakah sampel berasal dari populasi yang berdistribusi normal. Hasil analisis uji normalitas yang dilakukan dengan bantuan aplikasi SPSS 21 pada variabel $X$ dan variabel $\mathrm{Y}$ diketahui bahwa data berasal dari populasi berdistribusi normal. Hal ini ditunjukkan pada nilai output SPSS 21 Asymp Sig (2tailed) adalah 0,105 (lihat lampiran 4 halaman 76) yang artinya bahwa nilai tersebut lebih besar dari $\alpha$ pada taraf signifikan $5 \%$ (0.05). Sehingga $\mathrm{H}_{0}$ diterima dan $\mathrm{H}_{\mathrm{a}}$ ditolak, karena nilai Asymp Sig (2-tailed) $0.105>0.05$ $(5 \%)$ berarti data tersebut berasal dari data yang berdistribusi normal.

\section{b. Hasil Analisis Uji Homogenitas}

Uji homogenitas merupakan uji yang digunakan untuk mengetahui varian dari beberapa populasi yang sama atau tidak. Berdasarkan hasil analisis yang dilakukan dengan bantuan aplikasi SPSS 21 diketahui bahwa varian dari populasi data adalah sama atau homogen. Hal ini ditunjukkan pada hasil output SPSS 21 nilai signifikansi untuk variabel $\mathrm{X}$ berdasarkan variabel $\mathrm{Y}$ adalah 0,845 (lihat lampiran 5 halaman 77 ). Sehingga 0,845 >0,05, maka dapat dikatakan bahwa varian berasal dari populasi data yang sama atau homogen.

\section{c. Hasil Analisis Uji Linieritas}

Uji linieritas merupakan uji yang bertujuan untuk mengetahui apakah dua variabel mempunyai hubungan yang linier atau tidak secara signifikan. Hasil analisis uji linieritas yang dilakukan dengan bantuan aplikasi SPSS 21 pada variabel $\mathrm{X}$ dan variabel $\mathrm{Y}$ diketahui bahwa data mempunyai hubungan 
yang linier. Hal ini ditunjukkan pada nilai hasil output SPSS 21 nilai signifikansi yang diperoleh adalah 0,845 (lihat lampiran 6 halaman 78). Sehingga $0,845>0,05$, maka dapat dikatakan bahwa dua variabel mempunyai hubungan yang linier.

\section{Hasil Analisis Uji Hipotesis}

\section{a. Hasil Analisis Korelasi Product Moment}

Hasil analisis Product Moment diperoleh koefisien korelasinya adalah 0,783 (lihat lampiran 8 halaman 81). Dari koefisien korelasi yang ditemukan sebesar 0,783 , maka untuk mengetahui bahwa koefisien korelasinya signifikan dan untuk mengetahui apakah hasil analisis data tersebut dapat digunakan sebagai kesimpulan terhadap populasinya maka koefisien korelasi hitung (rh) sebesar 0,783 dibandingkan dengan koefisien korelasi tabel (rt) sebesar 0,355 yang terdapat pada nilai $r$ Product Moment. Jika rh $>\mathrm{r}$ tabel maka korelasinya signifikan dan apabila $\mathrm{rh} \leq \mathrm{rt}$ aka korelasinya tidak signifikan.

\section{b. Hasil Analisis Uji Signifikansi}

Hasil uji signifikansi korelasi antara variabel $\mathrm{X}$ dan variabel $\mathrm{Y}$ diperoleh nilai t hitung sebesar 4,790 (lihat lampiran 9 halaman 82). Selanjutnya dibandingkan dengan harga $t$ tabel pada taraf signifikan 5\% dan $\mathrm{dk}(\mathrm{n}-2)$ diperoleh $\mathrm{t}$ tabel sebesar 1,699. Karena t hitung lebih besar dari t tabel, maka dapat disimpulkan bahwa terdapat korelasi yang signifikan antara penguasaan kosakata bahasa Jerman (X) dengan kererampilan menulis kalimat sederhana (Y).

\section{c. Hasil Analisis Persamaan Regresi Sederhana}

Setelah di analisis melalui analisis persamaan regresi sederhana dan diperoleh persamaan regresinya adalah $\mathrm{Y}=0,53+0,22 \mathrm{X}$ (lihat lampiran 10 halaman 83). Hal ini berarti bila harga $X$ adalah 30, maka skor yang mungkin dicapai (variabel Y) adalah 7,13. Ini berarti bahwa setiap kenaikan variabel $\mathrm{X}$ akan di ikuti oleh kenaikan variabel $Y$. Sehingga dapat disimpulkan bahwa variabel $X$ berpengaruh terhadap variabel Y.

\section{d. Hasil Analisis Koefisien Determinasi}

Setelah dilakukan penghitungan menggunkan rumus $\mathrm{KD}$, diketahui bahwa sumbangan variabel penguasaan kosakata Bahasa Jerman (X) kepada variabel keterampilan menulis kalimat sederhana Bahasa Jerman adalah sebesar 13,96\% (lihat lampiran11 halaman 84). Dengan begitu, dapat disimpulkan bahwa berdasarkan tabel pedoman Intrepertasi Koefisien Determinasi dengan $13,96 \%$ diketahui bahwa terdapat pengaruh yang rendah antara variabel $\mathrm{X}$ dengan variabel $\mathrm{Y}$ tetapi pengaruh yang pasti.

Penelitian ini terdiri dari dua tes yaitu tes penguasaan kosakata bahasa Jerman dan tes keterampilan menulis kalimat sederhana bahasa Jerman. Data dari hasil penelitian tes penguasaan kosakata bahasa Jerman terdiri atas empat jenis tes dengan 50 soal, yaitu menentukan kata benda 
(Nomen), tes menentukan sifat (Adektiv), kata kerja (Verb), kata penghubung (Konjunktion) dan Kata bilangan (Zahlwörter). Tes tersebut memiliki skor maksimal 50. Berdasarkan data yang telah diolah dari kelima macam tes kosakata yang telah diberikan, maka skor rata-rata yang diperoleh siswa pada tes menentukan kata benda adalah 7 , kemudian skor rata-rata pada tes menentukan kata sifat adalah 8,61 selanjutnya pada tes menentukan kata kerja adalah 6,64 dan tes menentukan kata penghubung adalah 7,09 serta skor rata-rata yang diperoleh pada tes menentukan kata bilangan adalah 6,54 .

Data dari hasil penelitian tes keterampilan menulis kalimat sederhana bahasa Jerman yang diberikan memiliki skor maksimal 9. Dari tes tersebut, maka diperoleh skor terendah yang dicapai siswa adalah 3 dan skor tertinggi yang dicapai siswa adalah 8. Adapun skor rata-rata siswa adalah 6,12 dengan persentase sebesar $68 \%$..

Skor yang diperoleh siswa pada tes penguasaan penguasaan kosakata dan keterampilan menulis kalimat sederhana dianalisis dengan menggunakan teknik korelasi Product Moment. Dari hasil perhitungan diperoleh hasil bahwa rh lebih besar daripada rt $(0,783>0,355)$. Dengan demikian dapat disimpulkan bahwa terdapat korelasi yang signifikan antara penguasaan kosakata bahasa Jerman dengan keterampilan menulis kalimat sederhana.
Penguasaan kosakata bahasa Jerman berperan penting terhadap keterampilan menulis kalimat, seperti menulis kalimat sederhana. Dalam menulis kalimat bahasa Jerman, siswa dilatih untuk membuat kalimat bahasa Jerman dengan baik dan benar. Namun siswa memiliki kendala dalam pembelajaran menulis. Hal ini disebabkan minimmya penguasaan kosakata siswa yang membuat mereka sulit dalam membuat kalimat. Misalnya siswa menulis suatu kalimat akan tetapi mereka sulit menuliskanya karena kurangnya kosakata yang siswa miliki.

Keterampilan menulis adalah suatu keterampilan berbahasa untuk mengungkapkan pikiran, gagasan dan ide dalam bentuk tulisan. Dalam pembelajaran menulis bahasa Jerman, siswa dilatih untuk membuat kalimat bahasa Jerman dengan baik dan benar. Salah satu kegiatan menulis adalah menulis kalimat sederhana. Menulis kalimat sederhana adalah kalimat yang terdiri dari subjek, predikat dan objek/pelengkap. Dalam membuat suatu kalimat yang sederhana diperlukan penguasaan kosakata yang memadai.

Penguasaan kosakata dapat membantu dalam membuat suatu kalimat, karena dapat menunjang kualitas keterampilan menulis siswa. Siswa yang mempunyai kosakata yang memadai dapat menentukan kualitas keterampilan berbahasanya. Semakin banyak kosakata yang dimiliki seseorang, semakin terampil pula dalam berbahasa, dalam hal ini 
adalah keterampilan menulis kalimat sederhana.

Berdasarkan hal tersebut di atas maka dapat disimpulkan bahwa penguasaan kotakata mempengaruhi keterampilan menulis kalimat bahasa Jerman. Penguasaan kosakata dalam menulis kalimat sederhana bahasa Jerman memberikan konstribusi yang sangat besar. Dengan kata lain siswa yang tidak memiliki pengusaan kosakata yang baik akan kesulitan dalam membuat kalimat khususnya kalimat sederhana dalam bahasa Jerman. Semakin banyak kosakata yang dimiliki siswa, semakin baik pula keterampilan menulis siswa, dalam hal ini adalah keterampilan menulis kalimat sederhana bahasa Jerman. Hal ini didukung oleh pendapat yang dikemukakan oleh Tarigan (2011: 2) bahwa kualitas keterampilan berbahasa seseorang sangat dipengaruhi pada kualitas dan kuantitas kosakata yang dimilikinya. Semakin kaya kosakata yang dimiliki, semakin terampil pula dalam berbahasa.

\section{KESIMPULAN}

1. Tingkat penguasaan kosakata bahasa Jerman siswa adalah berada pada kategori cukup dengan skor rata-rata 35,9 dengan persentase sebesar $71,8 \%$.

2. Tingkat keterampilan menulis kalimat sederhana bahasa Jerman adalah berada pada kategori cukup dengan rata-rata 6,12 dengan persentase sebesar $68 \%$.

3. Terdapat korelasi positif yang signifikan antara penguasaan kosakata bahasa Jerman dengan keterampilan menulis kalimat sederhana. Hal ini ditunjukkan dengan koefisien korelasi sebesar 0.783 yang termasuk dalam kategori kuat.

\section{DAFTAR PUSTAKA}

Ba'dulu, Muis. 2005. Morfosintaksis. Jakarta: Rieneka Cipta.

Chaer, Abdul. 2006. Tata Bahasa Praktis Bahasa Indonesia. Jakarta: PT. Rineka

Djiwandono, Soenardi. 2011. Tes Bahasa Pegangan Bagi Pengajar Bahasa. Malang: PT Indeks.

Haryati. 2006. Keterampilan Psikomotor dan Prosedural Siswa. Bandung.

Irhana. 2015. Hubungan antara Penguasaan Kosakata dengan Keterampilan Menulis Surat Pribadi Bahasa Jerman Siswa Kelas XI Bahasa SMA Negeri 1 Bontonompo Kabupaten Gowa. Skripsi pada Jurusan Pendidikan Bahasa Jerman UNM: tidak diterbitkan

Junus, Muhammad dan Junus, Fatimah. 2011. Keterampilan Berbahasa Tulis. Makassar: Badan Penerbit Umum.

Karagiannakis, Evangelia. 2009. Schreiben in der Gruppe-Ein Kooperativer Lernprozess. München: Goethe InstitutHeuber Freude an Sprachen.

Marcia, Celce. 2001. Teaching English as Second Language 
(Third Edition). New York: Hemle and Hemle.

Mulyati, Yeti. 2007. Keterampilan Berbahasa Indonesia SD. Jakarta: Universitas terbuka.

Nunan, David. 1991. Language Teaching Methodologi. Sydney: Prentice Hill

Nurgiyantoro, Burhan. 2010. Penelitian dalam Pengajaran Bahasa dan Sastra. Yogyakarta: BPFE.

Pua, Siti Hajar. 2013. Peningkatan Keterampilan Menulis Kalimat Sederhana Bahasa Jerman Melalui Media Kartu Kata Siswa Kelas XI IPA SMA Negeri 1 Sunggminasa. Skripsi pada jurusan Pendidikan Bahasa Jerman UNM: tidak diterbitkan.

Putrayasa. 2012. Jenis Kalimat Dalam Bahasa Indonesia. Bandung: PT. Refika Aditama.

Saadiah, Gisti. 2013. Hubungan Penguasaan Kosakata dengan Kemampuan Menulis Dialog Bahasa Jerman Siswa Kelas XII SMAN 18 Bandung. Skripi: Univeritas Pendidikan Indonesia: Bandung

Soedjito. 1992. Kosakakata Bahasa Indonesia. Jakarta: PT Gramedia Pustaka Utama

Steets, Angelika dan Echlich, Konrad. 2003. Wissenschaftlich Schreiben: Lehrer und lernen. Walter de.
Tarigan, Henry Guntur. 2011. Pengajaran Kosakata. Bandung: Angkasa.

Ulrich, Winfried. 2007.

Wortschatzarbeit im muttersprachlichen Deutschunterricht. Baltmannsweiler: Schneider Verlag Hoengehren.

Wiyanto, Asul. 2004. Terampil Menulis Paragraf. Jakarta: PT Gramedia Widiasarana Indonesia.

Zainurrahman. 2011. Menulis dari Teori Hingga Praktik. Bandung : Alfabeta 